\title{
Metody i techniki stosowane w systemach telemetrycznych i teleinformatycznych w obszarze audiologii - studia literaturowe
}

\section{Methods and techniques for use in telemetry and teleinformation and communications systems \\ - literature studies}

\section{Marika Kruszyńska, Aleksandra Pieczykolan, Tomasz Wiśniewski, Artur Lorens, Henryk Skarżyński}

Instytut Fizjologii i Patologii Słuchu, Światowe Centrum Słuchu, Zakład Implantów i Percepcji Słuchowej, Warszawa/Kajetany

Adres autora: Marika Kruszyńska, Światowe Centrum Słuchu, Zakład Implantów i Percepcji Słuchowej, ul. Mokra 17, Kajetany, 05-830 Nadarzyn, e-mail: m.kruszynska@ifps.org.pl

\section{Streszczenie}

Systemy telemetryczne i teleinformatyczne mają szerokie zastosowanie, szczególnie w medycynie. Ośrodki medyczne na całym świecie coraz częściej inwestują w najnowsze technologie, dając możliwość konsultacji i wykonywania badań drogą elektroniczną. Telemedycyna, która opiera się na systemach telemetrycznych i teleinformatycznych, pozwala oszczędzić czas oraz zapewnia nową jakość konsultacji i możliwość szybszego wykrycia schorzeń u pacjentów.

Celem pracy był przegląd literatury w celu analizy częstości i celu stosowania poszczególnych metod i technik pod kątem wykorzystania w systemach telemetrycznych i teleinformatycznych.

Dokonano przeglądu literatury, zaczynając od znalezienia synonimów oraz definicji telemedycyny.

W literaturze opisano korzyści oraz skuteczność metod i technik systemów telemetrycznych i teleinformatycznych, a także jakie systemy telemetryczne i teleinformatyczne są najczęściej stosowane.

Stosowanie systemów telemetrycznych i teleinformatycznych w audiologii pozwala na skrócenie czasu dojazdu pacjentów do ośrodka, obniżenie kosztów ponoszonych przez pacjentów, dzięki czemu poprawia się jakość ich życia. Miernikiem przydatności klinicznej metod i technik stosowanych w teleaudiologii jest częstość ich stosowania.

Słowa kluczowe: systemy telemetryczne • systemy teleinformatyczne $\bullet$ telemedycyna $\bullet$ teleaudiologia

Abstract

Telemetry and teleinformation and communications systems are used in different ways, esspecially in medicine. All over the world medical centers are investing in new technology, which gives an opportunity for teleconsultation and telemedicine examination. Telemedicine allows to save time, gives new quality for medical consultation and an oportunity to find a disease faster.

The aim of this work was literaure studies to analyse the frequency and to find aims of the use of particular methods and techniques in telemetry and teleinformation and communications systems.

The review of the literature began by finding synonyms and definitions of telemedicine.

The literature describes benefits, effectiveness of the methods and techniques used in telemetry and teleinformation and communications systems and which of them are used most offen. 
The use of telemetry and teleinformation and communications systems in audiology allows to shorten time which patients need to travel to a medical center. It allows to lower the coasts incurred by patients and improve their quality of life. The frequency of the use of methods and techniques in teleaudiology demonstrates their usefulness.

Key words: telemetry $\bullet$ teleinformation and communications systems $\bullet$ telemedicine $\bullet$ teleaudiology

\begin{abstract}
Wstęp
Systemy teleinformatyczne zdefiniowane są w ustawie o świadczeniu usług drogą elektroniczną. W myśl tej ustawy system teleinformatyczny jest to „zespół współpracujących ze sobą urządzeń informatycznych i oprogramowania, zapewniający przetwarzanie i przechowywanie, a także wysyłanie i odbieranie danych poprzez sieci telekomunikacyjne za pomocą właściwego dla danego rodzaju sieci urządzenia końcowego [1] (urządzenie telekomunikacyjne lub jego podzespół przeznaczony do współpracy z siecią publiczną, dołączane bezpośrednio lub pośrednio do zakończenia sieci publicznej [2])”. Telemetria w literaturze definiowana jest jako wszystkie czynności związane $\mathrm{z}$ wykonaniem pomiaru na odległość oraz z monitorowaniem, czy dane urządzenie działa poprawnie [3,4].
\end{abstract}

Systemy telemetryczne będą składały się więc z urządzenia pomiarowego oraz systemu teleinformatycznego pozwalającego na sterowanie urządzeniem pomiarowym na odległość oraz umożliwiającego przesyłanie wyników pomiarów przez sieci telekomunikacyjne [1].

Systemy telemetryczne i teleinformatyczne są szeroko stosowane w wielu dziedzinach, szczególnie w medycynie.

Coraz więcej ośrodków medycznych na świecie inwestuje w najnowsze technologie, dając możliwość konsultacji i wykonywania badań drogą elektroniczną. Telemedycyna oparta na systemach telemetrycznych i teleinformatycznych staje się podstawowym środkiem opieki zdrowotnej na takich kontynentach jak Europa, Australia, Afryka czy Ameryka Północna [5-9].

Telemedycyna definiowana jest jako różnego rodzaju usługi medyczne, świadczone z wykorzystaniem nowoczesnych rozwiązań technologicznych i łączenia się za pomocą Internetu z jednostką współpracującą z ośrodkiem, w którym przyjmowani są pacjenci potrzebujący konsultacji z konkretnym specjalistą. Konsultacja nie odbywa się twarzą w twarz z pacjentem, a możliwa jest bez względu na to, jak daleko znajduje się ośrodek współpracujący z placówką świadczącą usługi medyczne [5,7,10-25].

Jedną z podkreślanych przez autorów zalet telemedycyny jest łatwiejszy dostęp do specjalisty bez względu na odległość, jaka dzieli pacjenta i lekarza. Dużo łatwiej bowiem pacjentowi dojechać do najbliższego ośrodka i dzięki telekonsultacjom być pod opieką specjalisty.

Telemedycyna pozwala nie tylko na oszczędność czasu, lecz zapewnia także nową jakość konsultacji i możliwość szybszego wykrycia schorzenia u danego pacjenta. Te cechy telemedycyny wykorzystywane są szczególnie w kardiologii, gdzie pacjent jest monitorowany przez całą dobę [26]. Właśnie dlatego telemedycyna staje się coraz bardziej popularna i stąd tak wiele jest teledziedzin medycyny, m.in. telekardiologia, teleradiologia, telescreening dzieci w wieku szkolnym, telerehabilitacja, opieka telemedyczna nad pacjentami chorymi na cukrzycę, opieka nad nowonarodzonymi dziećmi bez konieczności wizyt rodziców w szpitalu czy wizyt położnej w domu małego pacjenta, opieka nad pacjentami w podeszłym wieku, czy wreszcie teleaudiologia, a szczególnie telefitting, czyli metoda oparta na zdalnym programowaniu procesora mowy użytkowników systemu implantu ślimakowego [27-34].

Z definicji zamieszczonych w publikacjach wynika, że teleaudiologia, podobnie jak telemedycyna, wykorzystuje najnowsze technologie i łączenie się za pomocą Internetu z jednostką współpracującą z ośrodkiem, w którym przyjmowani są pacjenci potrzebujący opieki audiologicznej $[23,35,37-39]$.

Natomiast telefitting, inaczej zwany zdalnym fittingiem (ang. remote fitting), jest dziedziną teleaudiologii skierowaną do pacjentów korzystających z systemu implantu ślimakowego. System implantu ślimakowego jest protezą słuchu, która dzięki stymulacji elektrycznej zakończeń nerwu słuchowego zastępuje uszkodzony narząd receptorowy ślimaka. Złożony jest z części wewnętrznej (kapsuła oraz elektrody) wszczepianej operacyjnie i części zewnętrznej, czyli procesora mowy, który przetwarza dźwięk na bodziec elektryczny zgodnie z określoną strategią kodowania mowy [39]. Z definicji zawartych w literaturze wynika, że telefitting jest to programowanie procesora mowy i łączenie się przez Internet $\mathrm{z}$ miejscem współpracującym $\mathrm{z}$ ośrodkiem, w którym przyjmowani są pacjenci korzystający z systemu implantu ślimakowego. Organizowane są konsultacje, w czasie których inżynier kliniczny wykonuje badania i dopasowuje procesor mowy pacjenta $[10,15,40-44]$.

Dopasowanie procesora mowy możliwe jest dzięki wykorzystaniu odpowiednich metod i technik. Podczas fittingu metody rozumiane są jako zespół teoretycznie uzasadnionych zabiegów koncepcyjnych i instrumentalnych, obejmujących najogólniej całość postępowania zmierzającego do uzyskania produktu, czyli skompensowania utraconej funkcji słyszenia. Natomiast techniki są to czynności praktyczne, regulowane starannie wypracowanymi procedurami, pozwalającymi na uzyskanie produktu danego podprocesu. Narzędziem jest element służący do realizacji wybranej techniki badań [45].

Metody i techniki wykorzystywane w praktyce klinicznej mogą okazać się przydatne, jeśli pozwalają osiągnąć założony cel ich stosowania. Miernikiem przydatności poszczególnych metod i technik opisanych w literaturze może być także częstość ich stosowania.

\section{Cel}

Celem pracy był przegląd literatury pod kątem analizy częstości i celu stosowania poszczególnych metod i technik 
pod kątem wykorzystania w systemach telemetrycznych i teleinformatycznych używanych $\mathrm{w}$ teleaudiologii, a w szczególności w telefittingu.

\section{Material i metoda}

W celu opracowania tematu pracy dokonano przeglądu literatury, który rozpoczęto od znalezienia synonimów oraz definicji telemedycyny.

$\mathrm{W}$ literaturze spotykamy się $\mathrm{z}$ wieloma różnymi synonimami słowa 'telemedycyna'. Autorzy chcąc podkreślić, że tematyka ich publikacji nawiązuje do świadczeń medycznych prowadzonych za pomocą łączy internetowych, dodają do określeń związanych z medycyną czy zdrowiem przedrostek tele- lub e-. Jednak zdarza się także, że określenia zawierają słowo 'zdalny' (ang. remote). Najczęściej występującym w literaturze określeniem jest 'telemedycyna' (ang. telemedicine). Do najczęściej spotykanych w literaturze synonimów 'telemedycyny' należą:

- telezdrowie (telehealth),

- ezdrowie (e-health),

- zdalna opieka zdrowotna (remote health care),

- teleopieka (telecare),

- zdalne konsultacje (remote-consultation),

- e-medycyna (e-medicine),

- telepraktyka (telepractice),

- technologia telekomunikacyjna (telecommunication technology),

- teleopieka nad słuchem (telehearing),

- telerehabilitacja (telerehabilitation),

- teleinterwencja (teleintervention),

- telemonitoring (telemonitoring) [5-8,10-19,28-31, 46-49].

Identyfikacja synonimów pozwoliła na wykonanie przeglądu literatury, który rozpoczęto od wyszukania artykułów na temat telemedycyny. Poszukiwania literatury poszerzono także o hasła obejmujące 'teleaudiologię oraz 'telefitting', gdyż dziedziny te są kluczowe w dalszych rozważaniach. Artykułów wyszukiwano za pomocą serwisu Pubmed IOvid, według algorytmu przedstawionego w załączniku 1, który został opracowany na podstawie synonimów telemedycyny, teleaudiologii oraz telefittingu.

Na podstawie przyjętego algorytmu wyszukano około pięciu tysięcy publikacji, które poddano selekcji. Selekcja polegała przede wszystkim na odrzuceniu artykułów, które nie były bezpośrednio związane $\mathrm{z}$ teleaudiologią, choć dotyczyły innych dziedzin telemedycyny, np. telekargiologii czy teleradiologii. Część publikacji nie była dostępna lub była w języku innym niż polski czy angielski. Kilka publikacji opierało się na wynikach badań na zwierzętach, dlatego te publikacje również odrzucono. W wyniku pogłębionej selekcji wybrano 46 pozycji literaturowych potrzebnych do przeglądu literatury na temat systemów telemetrycznych i teleinformatycznych. Na rycinie 1 przedstawiono sposób selekcjonowania i przyczyny, dla których odrzucono część artykułów.

Częstość stosowania poszczególnych metod i technik została określona jako procentowy udział artykułów, w których dane metody i techniki były używane do badań, w stosunku do wszystkich wyszukanych i analizowanych artykułów.

\section{Wyniki}

W tabeli 1 przedstawiono, jakie są korzyści oraz jaka jest skuteczność metod i technik systemów telemetrycznych i teleinformatycznych opisanych w literaturze, a także jakie systemy telemetryczne i teleinformatyczne są najczęściej stosowane przez autorów.

\section{Dyskusja i wnioski}

Literatura podaje, że najczęściej używane są komputery z systemami firmy Microsoft (65\%). W połowie artykułów opisano system teleinformatyczny wyposażony w terminale firmy Polycom.

Załącznik 1. Algorytm wyszukiwania literatury przedmiotu

Annex 1. Literature search algorithm

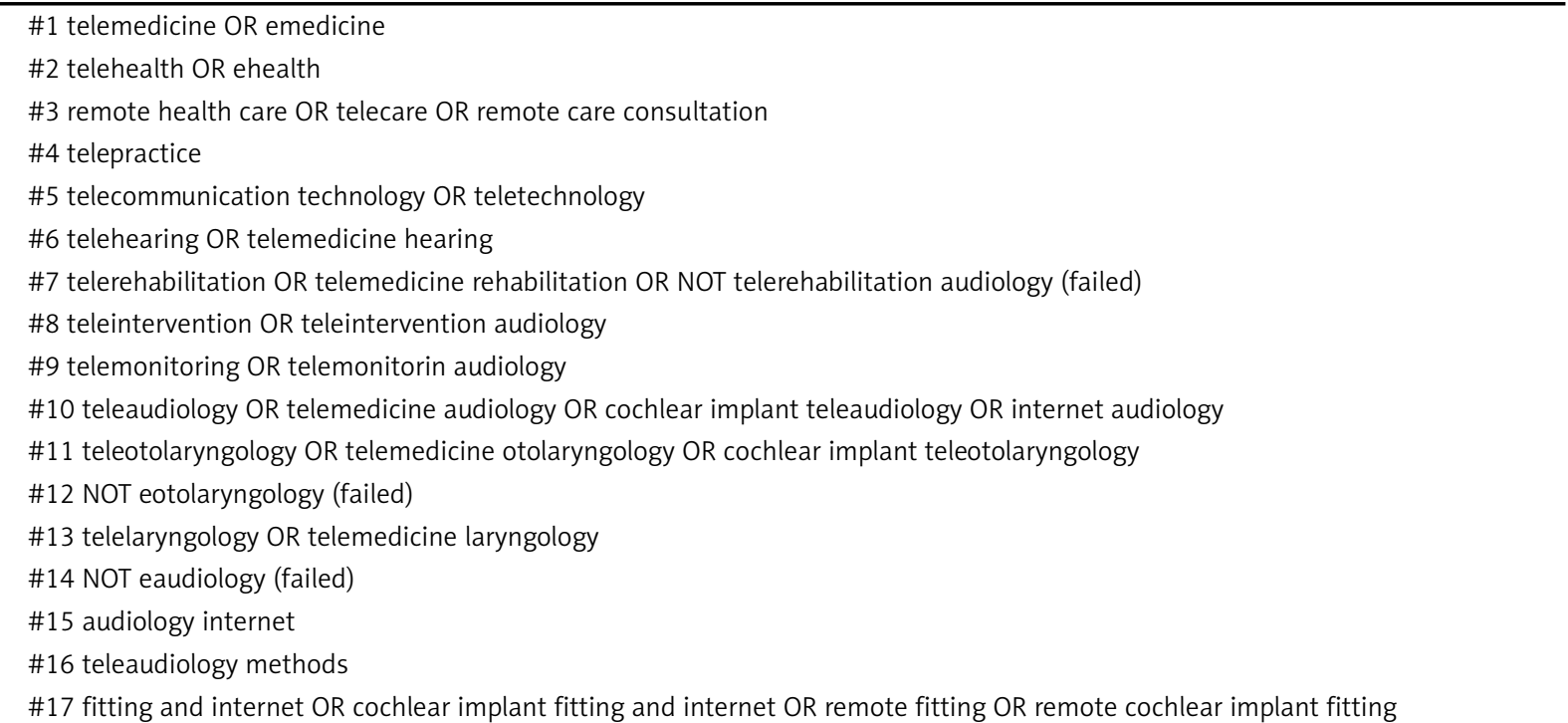




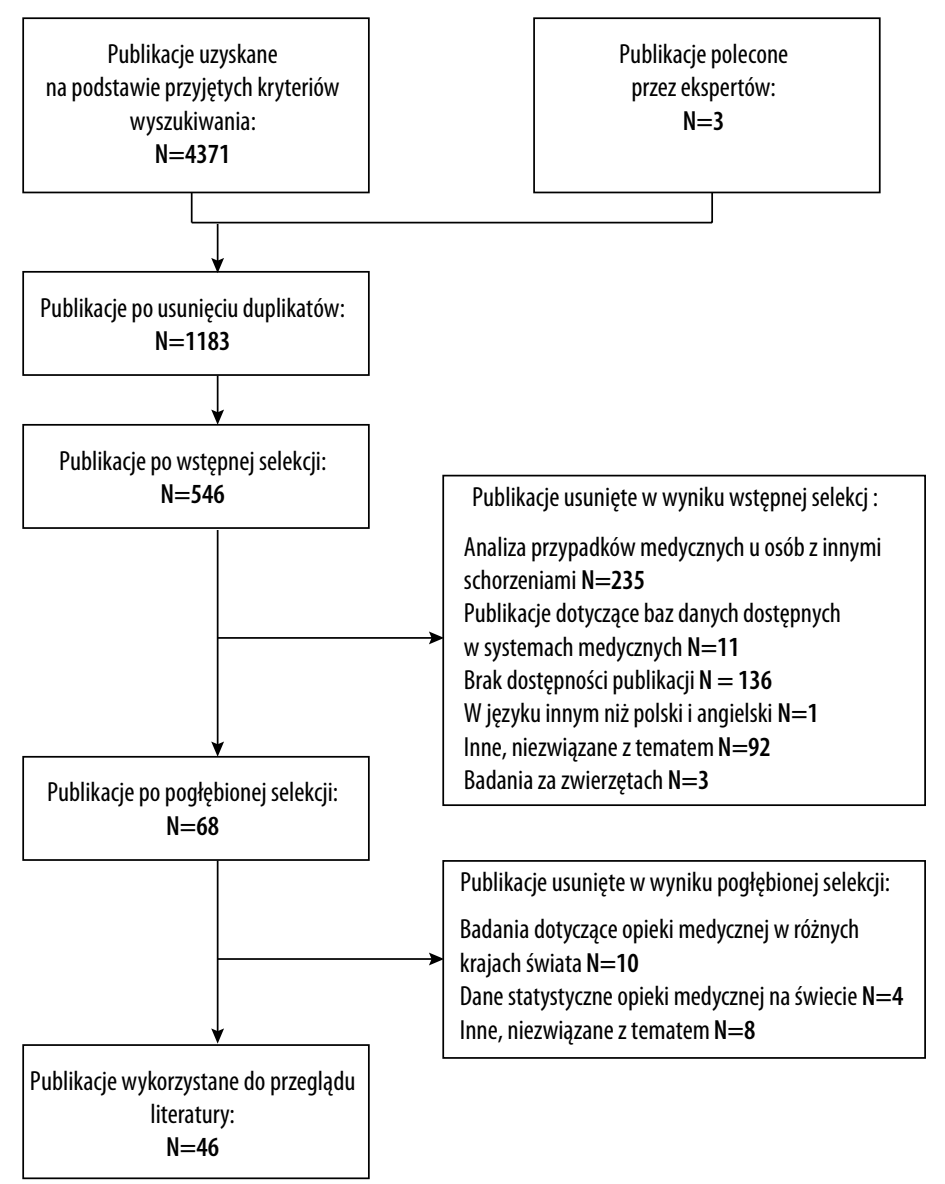

Rycina 1. Sposób selekcji oraz przyczyny odrzucenia publikacji

Figure 1. The literature selection method and the reasons for rejection of publications

Każdy artykuł opisuje różnego rodzaju pomiary, dlatego w zależności od wykonywanego badania autorzy posługują się innym systemem telemetrycznym. W 22\% artykułów autorzy używają do telefittingu programu Custom Sound. Również w 22\% artykułów autorzy wykorzystują audiometr Maico Diagnostics' MA40 do wykonywania audiometrii tonalnej podczas telekonsultacji. Pozostałe systemy telemetryczne opisane są w pojedynczych artykułach (tabela 1).

Na skrócenie czasu dojazdu pacjenta do ośrodka klinicznego jako główną korzyść wynikającą ze stosowania systemów telemetrycznych i teleinformatycznych wskazuje $86 \%$ artykułów [10,13,15,20,42-44]. W 43\% artykułów wymieniona jest kolejna korzyść wynikająca ze stosowania rozwiązań teleinformatycznych i telemetrycznych, którą jest obniżenie kosztów ponoszonych przez pacjenta związanych z wizytą w ośrodku klinicznym $[20,23,34,43,44,50]$.

Głównym miernikiem skuteczności stosowania systemów telemetrycznych i teleinformatycznych jest zadowolenie pacjentów z wizyty, o czym jest mowa w 36\% artykułów [13,33,41-43]. Część autorów wskazuje, że poprawa dostępu do specjalisty jest również dowodem na skuteczność wykorzystywanych metod teleaudiologicznych (29\% artykułów) $[15,22,23,41]$. W pojedynczych artykułach autorzy piszą także o poprawieniu jakości życia pacjentów oraz o możliwości szybszego wykrywania wad słuchu, zwłaszcza u dzieci w wieku szkolnym [34,50]. Jednocześnie wszyscy autorzy opisujący systemy telemetryczne i teleinformatyczne są zgodni co do przydatności tych systemów w codziennej praktyce klinicznej.

Najlepiej opisanymi w literaturze i najczęściej stosowanymi metodami są badania audiologiczne: otoemisje akustyczne (OAE), słuchowe potencjały wywołane pnia mózgu (ABR), audiometria tonalna, badania przesiewowe słuchu oraz badania za pomocą otoskopu [20,22-24,33,38,49,50].

Metody wykorzystywane podczas telefittingu, opisane przez autorów, są powszechne w codziennej praktyce klinicznej. Zaliczamy do nich pomiar telemetryczny wewnętrznej części systemu implantu ślimakowego, badanie odpowiedzi z nerwu słuchowego (ART/NTR/NRI - skróty oznaczające ten sam pomiar w różnych systemach implantu ślimakowego) oraz badanie odruchu z mięśnia strzemiączkowego wywołanego elektrycznie (eSR) [43,44,51].

Do wykonania wszystkich opisanych badań podczas konsultacji teleaudiologicznych konieczne jest połączenie komputerów w dwóch współpracujących ze sobą ośrodkach. Zatem potrzebne są: komputer $\mathrm{z}$ właściwym oprogramowaniem, połączenie internetowe oraz system umożliwiający połączenie ze sobą dwóch ośrodków. W większości artykułów wspomina się o korzystaniu z terminali firmy Polycom [20,22-24,33,38,49,50]. 
Tabela 1. Korzyści i skuteczność metod i technik systemów telemetrycznych i teleinformatycznych opisanych w literaturze Table 1. Benefits described in the literature and effectiveness of the methods and techniques use in telemetry and teleinformation and communications systems

\begin{tabular}{|c|c|c|c|c|c|c|c|}
\hline Lp. & Autor & $\begin{array}{c}\text { System } \\
\text { teleinformatyczny }\end{array}$ & $\begin{array}{c}\text { System } \\
\text { telemetryczny }\end{array}$ & Metoda & Technika & Korzyści & $\begin{array}{c}\text { Miernik } \\
\text { skuteczności }\end{array}$ \\
\hline 1 & $\begin{array}{l}\text { Botros } \\
\text { i wsp. } 2013\end{array}$ & $x$ & Custom Sound & $\begin{array}{l}\text { pomiar } \\
\text { elektrofizjologiczny }\end{array}$ & $\begin{array}{l}\text { AutoNRT (pomiar } \\
\text { odpowiedzi z nerwu } \\
\text { słuchowego) }\end{array}$ & $\begin{array}{l}\text { skrócenie czasu } \\
\text { ustawiania } \\
\text { implantu } \\
\text { ślimakowego }\end{array}$ & $x$ \\
\hline 2 & $\begin{array}{l}\text { Campos } \\
\text { i wsp. } 2012\end{array}$ & $\begin{array}{l}\text { Polycom PVX wersja } \\
\text { 8.0.2, komputery } \\
\text { stacjonarne } \\
\text { połączone } \\
\text { z internetem } \\
\text { (LAN USP) i dwa } \\
\text { komputery } \\
\text { połączone } \\
\text { z oprogramowaniem } \\
\text { HI-Pro i urządzeniem } \\
\text { Probe Mic. Do } \\
\text { telekonsultacji użyto } \\
\text { kamery Logitech }{ }^{\circledR} \\
\text { QuickCam Orbit. } \\
\text { Na komputerach } \\
\text { zainstalowano } \\
\text { system Windows } \\
\text { XP z procesorem } \\
\text { Pentium IV }\end{array}$ & $\begin{array}{l}\text { oprogramowanie } \\
\text { HINT PRO }\end{array}$ & pomiary in situ & $\begin{array}{l}\text { pomiary dla } \\
\text { użytkowników } \\
\text { aparatów } \\
\text { słuchowych: } \\
\text { odpowiedzi z ucha } \\
\text { bez aparatu (REUR), } \\
\text { odpowiedzi z ucha } \\
\text { w aparacie (REAR) } \\
\text { i pomiar zysku } \\
\text { z aparatowania } \\
\text { (REIG) }\end{array}$ & $x$ & $\begin{array}{l}\text { zadowolenie } \\
\text { pacjentów } \\
\text { z telefittingu } \\
\text { sprawdzone } \\
\text { za pomocą } \\
\text { kwestionariusza } \\
\text { IOI-HA } \\
\text { (International } \\
\text { Outcome } \\
\text { Inventory for } \\
\text { Hearing Aids) }\end{array}$ \\
\hline 3 & $\begin{array}{l}\text { Crowell } \\
\text { i wsp. } 2011\end{array}$ & $\begin{array}{l}\text { Polycom, system } \\
\text { Windows } 2003 \text { Pro } \\
\text { Virtual Server }\end{array}$ & OTOpod audiometr & $\begin{array}{l}\text { pomiary } \\
\text { elektrofizjologiczne } \\
\text { i psychofizyczne }\end{array}$ & $\begin{array}{l}\text { DPOAE, } \\
\text { audiometria } \\
\text { tonalna }\end{array}$ & $\begin{array}{l}\text { obniżenie } \\
\text { kosztów } \\
\text { i skrócenie } \\
\text { czasu dojazdu } \\
\text { pacjenta do } \\
\text { ośrodka }\end{array}$ & $x$ \\
\hline 4 & $\begin{array}{l}\text { Elangovan } \\
2005\end{array}$ & $\begin{array}{l}\text { komputery } \\
\text { z systemem } \\
\text { Microsoft } \\
\text { Windows lub Palm } \\
\text { OS połączone } \\
\text { z audiometrem }\end{array}$ & $\begin{array}{l}\text { audiometr Maico } \\
\text { Diagnostics' MA40 }\end{array}$ & $\begin{array}{l}\text { pomiar } \\
\text { elektorfizjologiczny }\end{array}$ & tele-OAE & $\begin{array}{l}\text { skrócenie } \\
\text { czasu dojazdu } \\
\text { pacjenta do } \\
\text { ośrodka }\end{array}$ & $\begin{array}{l}\text { zadowolenie } \\
\text { pacjenta } \\
\text { z telekonsultacji }\end{array}$ \\
\hline 5 & $\begin{array}{l}\text { Givens } \\
\text { i wsp. } 2003\end{array}$ & $\begin{array}{l}\text { komputery } \\
\text { z systemem } \\
\text { Microsoft } \\
\text { Windows lub Palm } \\
\text { OS połączone } \\
\text { z audiometrem za } \\
\text { pomocą 8-bitowego } \\
\text { kontrolera Microchip } \\
\text { Technology's PiC } \\
\text { 16C74B }\end{array}$ & $\begin{array}{l}\text { audiometr Maico } \\
\text { Diagnostics' MA40 }\end{array}$ & pomiar psychofizyczny & $\begin{array}{l}\text { audiometria } \\
\text { tonalna }\end{array}$ & $x$ & $\begin{array}{l}\text { dostęp } \\
\text { do badań } \\
\text { audiologicznych } \\
\text { dla osób, } \\
\text { które w swojej } \\
\text { okolicy nie mają } \\
\text { możliwości } \\
\text { udania się do } \\
\text { specjalistów }\end{array}$ \\
\hline 6 & $\begin{array}{l}\text { Hughes } \\
\text { i wsp. } 2012\end{array}$ & $\begin{array}{l}\text { Polycom, } \\
\text { z komputerem } \\
\text { Dell Latitude } \\
\text { E6400 z systemem } \\
\text { Windows XP }\end{array}$ & $\begin{array}{l}\text { Custom Sound } \\
\text { i Custom Sound EP } \\
\text { (wersja } 2.0 \text { upgrade } \\
3.2 \text { ) }\end{array}$ & $\begin{array}{l}\text { pomiary } \\
\text { elektrofizjologiczne }\end{array}$ & $\begin{array}{l}\text { NRT i pomiar } \\
\text { telemetryczny }\end{array}$ & $\begin{array}{l}\text { oszczędność } \\
\text { czasu }\end{array}$ & $\begin{array}{l}\text { łatwiejszy } \\
\text { dostęp do } \\
\text { specjalisty }\end{array}$ \\
\hline 7 & $\begin{array}{l}\text { Krumm } \\
\text { i wsp. } 2005\end{array}$ & $\begin{array}{l}\text { komputer Macintosh } \\
\text { Ilsi wyposażony } \\
\text { w modem } 33.6 \\
\text { kbaud, połączony } \\
\text { z internetem (LAN) }\end{array}$ & $\begin{array}{l}\text { system Virtual } \\
\text { otoacoustic } \\
\text { emissions (OAE) }\end{array}$ & $\begin{array}{l}\text { pomiar } \\
\text { elektrofizjologiczny }\end{array}$ & DPOAE & $\begin{array}{l}\text { obniżenie } \\
\text { kosztów } \\
\text { dojazdu } \\
\text { do ośrodka }\end{array}$ & $\begin{array}{l}\text { łatwiejszy } \\
\text { dostęp do } \\
\text { specjalisty }\end{array}$ \\
\hline 8 & $\begin{array}{l}\text { Lancaster } \\
\text { i wsp. } 2008\end{array}$ & $\begin{array}{l}\text { program Vcon ViGO, } \\
\text { system Windows } \\
\text { XP z procesorem } \\
\text { Pentium IV }\end{array}$ & $\begin{array}{l}\text { tympanometr Auto } \\
\text { Tymp screener, } \\
\text { wideootoskop } \\
\text { MedRx, audiometr } \\
\text { MA } 40\end{array}$ & pomiary psychofizyczne & $\begin{array}{l}\text { otoskopia, } \\
\text { tympanometria, } \\
\text { audiometria } \\
\text { tonalna }\end{array}$ & $\begin{array}{l}\text { możliwość } \\
\text { wykonywania } \\
\text { badań } \\
\text { przesiewowych } \\
\text { w wielu } \\
\text { szkołach przez } \\
\text { jeden ośrodek, } \\
\text { zmniejszenie } \\
\text { kosztów }\end{array}$ & $\begin{array}{l}\text { lepsza } \\
\text { wykrywalność } \\
\text { niedosłuchów } \\
\text { u dzieci } \\
\text { w wieku } \\
\text { szkolnym }\end{array}$ \\
\hline
\end{tabular}




\begin{tabular}{|c|c|c|c|c|c|c|c|}
\hline Lp. & Autor & $\begin{array}{c}\text { System } \\
\text { teleinformatyczny }\end{array}$ & $\begin{array}{c}\text { System } \\
\text { telemetryczny }\end{array}$ & Metoda & Technika & Korzyści & $\begin{array}{c}\text { Miernik } \\
\text { skuteczności }\end{array}$ \\
\hline 9 & $\begin{array}{l}\text { McElveen i } \\
\text { wsp. } 2010\end{array}$ & $\begin{array}{l}\text { Polycom V700, } \\
\text { system Microsoft } \\
\text { Windows XP } \\
\text { Professional } \\
\text { Version } 2002 \\
\text { wyposażony } \\
\text { w PingPlotter }\end{array}$ & $x$ & testy psychofizyczne & $\begin{array}{l}\text { test rozumienia } \\
\text { mowy w szumie } \\
\text { (HINT) i listy } \\
\text { wyrazów złożonych } \\
\text { z spółgłoski/ } \\
\text { samogłoski/ } \\
\text { spółgłoski (CNC) }\end{array}$ & $x$ & $\begin{array}{l}\text { nie ma } \\
\text { problemów } \\
\text { z połączeniem, } \\
\text { co daje } \\
\text { pacjentowi } \\
\text { poczucie } \\
\text { bezpieczeństwa } \\
\text { i pewność, że } \\
\text { ma łatwiejszy } \\
\text { dopstęp do } \\
\text { specjalisty }\end{array}$ \\
\hline 10 & $\begin{array}{l}\text { Ramos } \\
\text { i wsp. } 2009\end{array}$ & $\begin{array}{l}\text { laptop DELL latitude } \\
\text { d620 połączony } \\
\text { z internetem } \\
\text { i systemem } \\
\text { operacyjnym } \\
\text { Microsoft Windows } \\
\text { XP Professional } \\
\text { Service Pack2. } \\
\text { Do komunikacji } \\
\text { używano programu } \\
\text { Skype } 2.5\end{array}$ & SoundWave & $\begin{array}{l}\text { pomiar } \\
\text { elektrofizjologiczny }\end{array}$ & $\begin{array}{l}\text { pomiar odpowiedzi } \\
\text { z nerwu } \\
\text { słuchowego (NRI) }\end{array}$ & $\begin{array}{l}\text { wynik pomiaru } \\
\text { podczas } \\
\text { telefittingu } \\
\text { pokrywa się } \\
\text { z wynikiem } \\
\text { badania } \\
\text { wykonywanego } \\
\text { na żywo, } \\
\text { skrócenie czasu } \\
\text { wizyty pacjenta }\end{array}$ & \\
\hline 11 & $\begin{array}{l}\text { Wąsowski } \\
\text { i wsp. } 2012\end{array}$ & $\begin{array}{l}\text { terminale } \\
\text { telekonferencyjne } \\
\text { HDX8006 Polycom } \\
\text { z ekranami LCD } \\
\text { 32", ruchomymi } \\
\text { kamerami Polycom } \\
\text { oraz podłączeniem } \\
\text { do systemu } \\
\text { z symetrycznymi } \\
\text { łączami } \\
\text { internetowymi } \\
\text { o przepustowości } \\
2 \text { Mbit/s. W każdym } \\
\text { węźle znajduje } \\
\text { się komputer PC } \\
\text { z odpowiednimi } \\
\text { interfejsami } \\
\text { klinicznymi oraz } \\
\text { oprogramowaniem } \\
\text { do dopasowywania } \\
\text { implantów. } \\
\text { Funkcjonalność } \\
\text { pulpitu zdalnego } \\
\text { zapewnia aplikacja } \\
\text { Longmein.com }\end{array}$ & $\begin{array}{l}\text { program } \\
\text { odpowiedni } \\
\text { dla danego } \\
\text { systemu implantu } \\
\text { ślimakowego }\end{array}$ & $\begin{array}{l}\text { pomiary } \\
\text { elektrofizjologiczne } \\
\text { i psychofizyczne }\end{array}$ & $\begin{array}{l}\text { pomiary } \\
\text { impedancji, } \\
\text { ECAP, pomiar } \\
\text { odruchu mięśnia } \\
\text { strzemiączkowego } \\
\text { wywołany } \\
\text { elektrycznie (ESR), } \\
\text { elektrycznie } \\
\text { wywołana funkcja } \\
\text { narastania } \\
\text { głośności, detekcja } \\
\text { progowa }\end{array}$ & $\begin{array}{l}\text { skrócenie } \\
\text { czasu dojazdu } \\
\text { do ośrodka, } \\
\text { zmniejszenie } \\
\text { kosztów dojazdu }\end{array}$ & $\begin{array}{l}\text { zadowolenie } \\
\text { pacjentów } \\
\text { z telefittingu }\end{array}$ \\
\hline 12 & $\begin{array}{l}\text { Wąsowski } \\
\text { i wsp. } 2010\end{array}$ & $\begin{array}{l}\text { Cztery komputery } \\
\text { połączone ze } \\
\text { sobą za pomocą } \\
\text { internetu, mikrofony, } \\
\text { kamery i głośniki. } \\
\text { Na komputerach } \\
\text { znajduje się } \\
\text { oprogramowanie } \\
\text { potrzebne do } \\
\text { telefittingu }\end{array}$ & $\begin{array}{l}\text { program } \\
\text { odpowiedni } \\
\text { dla danego } \\
\text { systemu implantu } \\
\text { ślimakowego }\end{array}$ & $\begin{array}{l}\text { pomiary } \\
\text { elektrofizjologiczne } \\
\text { i psychofizyczne }\end{array}$ & $\begin{array}{l}\text { pomiary } \\
\text { impedancji, } \\
\text { elektrycznie } \\
\text { wywołana funkcja } \\
\text { narastania } \\
\text { głośności }\end{array}$ & $\begin{array}{l}\text { skrócenie czasu } \\
\text { dojazdu do } \\
\text { ośrodka }\end{array}$ & $\begin{array}{l}\text { alternatywa dla } \\
\text { tradycyjnego } \\
\text { fittingu, } \\
\text { zadowolenie } \\
\text { pacjentów }\end{array}$ \\
\hline 13 & $\begin{array}{l}\text { Wesarg } \\
\text { i wsp. } 2010\end{array}$ & $\begin{array}{l}\text { Polycom PVX oraz } \\
\text { VidConference, } \\
\text { komputery } \\
\text { połączone ze sobą } \\
\text { za pomocą łącza } \\
\text { internetowego, } \\
\text { wyposażone } \\
\text { w programy do } \\
\text { telefittingu, kamery } \\
\text { i mikrofony }\end{array}$ & Custom Sound & $\begin{array}{l}\text { pomiary } \\
\text { elektrofizjologiczne } \\
\text { i psychoakustyczne }\end{array}$ & $\begin{array}{l}\text { telemetria, pomiar } \\
\text { odpowiedzi z nerwu } \\
\text { słuchowego } \\
\text { (NRT), skalowanie } \\
\text { głośności, zmiana } \\
\text { parametrów } \\
\text { stymulacji }\end{array}$ & $\begin{array}{l}\text { skrócenie } \\
\text { czasu dojazdu } \\
\text { pacjenta } \\
\text { do ośrodka, } \\
\text { zmniejszenie } \\
\text { kosztów podróży }\end{array}$ & \\
\hline
\end{tabular}




\begin{tabular}{|c|c|c|c|c|c|c|c|}
\hline Lp. & Autor & $\begin{array}{c}\text { System } \\
\text { teleinformatyczny }\end{array}$ & $\begin{array}{l}\text { System } \\
\text { telemetryczny }\end{array}$ & Metoda & Technika & Korzyści & $\begin{array}{c}\text { Miernik } \\
\text { skuteczności }\end{array}$ \\
\hline 14 & $\begin{array}{l}\text { Yao i wsp. } \\
2009\end{array}$ & $\begin{array}{l}\text { komputer } \\
\text { wyposażony } \\
\text { w system firmy } \\
\text { Microsoft, } \\
\text { z programowaniem } \\
\text { za pomocą techniki } \\
\text { AJAX (Asynchronous } \\
\text { Java-Script) }\end{array}$ & testy słuchowe & pomiar psychofizyczny & $\begin{array}{l}\text { audiometria } \\
\text { tonalna }\end{array}$ & $\begin{array}{l}\text { możliwość } \\
\text { wykonania } \\
\text { badania } \\
\text { w każdym } \\
\text { miejscu } \\
\text { i o każdej porze, } \\
\text { zmniejszenie } \\
\text { kosztów }\end{array}$ & $\begin{array}{l}\text { zwiększenie } \\
\text { jakości życia } \\
\text { pacjenta }\end{array}$ \\
\hline
\end{tabular}

Specjaliści mają możliwość zdalnego wykonywania badań. Jednak równie ważny jest asystent, który pomoże zarówno osobie badającej, jak i pacjentowi. Do zadań asystenta należy najczęściej odpowiednie umieszczenie słuchawek do badania audiometrycznego lub sondy pomiarowej w przypadku OAE, elektrod w odpowiednim miejscu na głowie pacjenta, gdy wykonywany będzie pomiar ABR, podłączenie procesora mowy do komputera $\mathrm{z}$ oprogramowaniem.

Możliwości technologiczne, pozwalające na wykonywanie badań w systemach telemetrycznych i teleinformatycznych, muszą być uzupełnione odpowiednim przygotowaniem specjalistów oraz asystentów do wykonywania powierzonych im zadań. Znajomość obsługi komputera czy programu nie jest wystarczająca do skutecznego wykonywania zadań powierzonych personelowi medycznemu. Personel powinien być przygotowany zarówno pod względem technicznym, jak i pod względem ogólnej wiedzy dotyczącej telemedycyny [52].

Autorzy w swoich artykułach porównali wyniki uzyskiwane przez pacjentów podczas telekonsultacji z tymi, jakie ci sami pacjenci uzyskali podczas tradycyjnie wykonywanego badania. W większości przypadków wyniki nie różniły się między sobą. Jeśli różnice występowały, nie przekraczały progu błędu pomiarowego [10,13,27,28,30,31,36,42].

Drugim sposobem, jaki wykorzystywali autorzy, chcąc sprawdzić przydatność metod używanych podczas telekonsultacji, były badania ankietowe wśród pacjentów. Wyniki ankiety pokazały, że osoby badane były zadowolone ze sposobu, w jaki były wykonywane badania, z możliwości uczestniczenia w badaniu w miejscu zamieszkania, bez konieczności pokonywania wielu kilometrów, żeby spotkać się ze specjalistą $[20,22-24,33,38,49,50]$.

Badania ankietowe były również podstawowym sposobem, jakiego używali autorzy, chcąc sprawdzić przydatność telefittingu. Wyniki ankiety pokazały, że pacjenci chcieliby ponownie uczestniczyć w takiej formie programowania procesora mowy. Również w przypadku telefittingu pacjenci wskazywali, że taka forma konsultacji nie wymaga przemierzania wielu kilometrów, żeby dostać się do ośrodka, zatem jest to rozwiązanie ekonomiczne, co zachęca pacjentów do brania udziału w zdalnym programowaniu procesora mowy $[43,44,51]$.

Telemedycyna wychodzi naprzeciw potrzebom pacjentów. Wykonany przegląd literatury pozwolił na stwierdzenie, że metody używane w teleaudiologii są efektywne, dają wiarygodne wyniki i - co najważniejsze - pacjenci cenią taką formę konsultacji ze specjalistą.
Publikacje potwierdzają przydatność badań audiometrycznych obiektywnych, takich jak otoemisje akustyczne (OAE), słuchowe potencjały wywołane pnia mózgu (ABR), oraz audiometrii tonalnej i badania uszu za pomocą otoskopu. Jeśli chodzi o metody do telefittingu, to doniesienia literaturowe potwierdzają przydatność pomiaru telemetrycznego wewnętrznej części systemu implantu ślimakowego, badania odpowiedzi z nerwu słuchowego (ART/NTR/NRI) i badania odruchu z mięśnia strzemiączkowego wywołanego elektrycznie (eSR).

Na szczególną uwagę zasługuje możliwość zdalnego badania słuchowych potencjałów wywołanych pnia mózgu (ABR), audiometrii tonalnej i badania odruchu z mięśnia strzemiączkowego wywołanego elektrycznie (eSR). Badania te wykonywane są u pacjentów, zarówno dzieci, jak i dorosłych, korzystających z systemu implantu ślimakowego. Włączenie ich do praktyki telefittingowej pacjentów z implantami pozwoliłoby na jeszcze skuteczniejszą interwencję. Specjalista zajmujący się programowaniem procesora mowy otrzymałby wynik badania, które jest mu potrzebne, natomiast pacjent nie musiałby przyjeżdżać do ośrodka, żeby takie badanie wykonać.

Reasumując, stosowanie systemów telemetrycznych i teleinformatycznych w audiologii pozwala na osiągnięcie następujących korzyści:

1) skrócenie czasu dojazdu pacjenta do ośrodka klinicznego, 2) obniżenie kosztów ponoszonych przez pacjenta w związ$\mathrm{ku} \mathrm{z}$ wizytami $\mathrm{w}$ ośrodku klinicznym oddalonym od miejsca zamieszkania,

3) zadowolenie pacjentów $z$ odbytych wizyt,

4) poprawa dostępu do specjalisty,

5) poprawa jakości życia pacjentów,

6) możliwość szybszego wykrywania wad słuchu.

Biorąc pod uwagę częstość stosowania jako miernik przydatności klinicznej metod i technik wykorzystywanych $\mathrm{w}$ teleaudiologii, do najbardziej przydatnych zalicza się: 1) badanie otoemisji akustycznych (OAE),

2) badanie słuchowych potencjałów wywołanych pnia mózgu (ABR),

3) pomiar telemetryczny u użytkowników systemu implantu ślimakowego,

4) badanie odpowiedzi z nerwu słuchowego u użytkowników systemu implantu ślimakowego,

5) badanie odruchu z mięśnia strzemiączkowego wywołanego elektrycznie (eSR) u użytkowników systemu implantu ślimakowego.

Artykut powstał $w$ związku $z$ realizacja projektu „Zintegrowany system narzędzi do diagnostyki i telerehabilitacji schorzeń narzqdów zmysłów (słuchu, mowy, równowagi, smaku, powonienia)" INNOSENSE, wspótfinansowanego przez Narodowe Centrum Badań i Rozwoju w ramach Programu STRATEGMED. 


\section{Piśmiennictwo:}

1. Ustawa z dnia 18 lipca 2002 r. o świadczeniu usług drogą elektroniczną.

2. Ustawa z dnia 21 lipca 2000 r. o prawie telekomunikacyjnym.

3. Henriques-Forsythe MN, Ivonye CC, Jamched U, Kamuguisha $\mathrm{LK}$, Olejeme KA, Onwuanyi AE. Is telemetry overused? Is it as helpful as thought? Cleve Clin J Med, 2009; 76(6): 368-72.

4. Mens LH. Advances in cochlear implant telemetry: Evoked neural responses, electrical field imaging, and technical integrity. Trends Amplif., 2007; 11(3): 143-59.

5. Mars M. Telemedicine and advances in urban and rural healthcare delivery in Africa. Prog Cardiovasc Dis, 2013; 56(3): 326-35.

6. Richards H, King G, Reid M, Selvaraj S, McNicol I, Brebner E i wsp. Remote working: survey of attitudes to Health of doctors and nurses in rural general practices in the United Kingdom. Fam Pract, 2005; 22(1): 2-7.

7. Saliba V, Legido-Quigley H, Hallik R, Aaviksoo A, Car J, McKee M. Telemedicine across borders: A systematic review of factors that hinder or support implementation. Int J Med Inform, 2012; 81(12): 793-809.

8. Sejdić E, Rothfuss MA, Stachel JR, Franconi NG, Bocan K, Lovell MR i wsp. Innovation and translation efforts in wireless medical connectivity, telemedicine and eMedicine: A story from the RFID Center of excellence at the University of Pittsburgh. Ann Biomed Eng, 2013; 41(9): 1913-25.

9. Lawrence G. Teleaudiology brings better hearing healthcare to Australia’s outback. Hearing Journal, 2012; 65(11).

10. Ramos A, Rodríguez C, Falcon JC, Martínez-Beneyto P, Gault A, Boyle P. Use of telemedicine in the remote programming of cochlear implants. Acta Oto-Laryngologica, 2009; 129 : $533-40$.

11. van den Berg N, Schumann M, Kraft K, Hoffmann W. Telemedicine and telecare for older patients - A systematic review. Maturitas, 2012; 73: 94-114.

12. Constantinescu G, Waite M, Dornan D, Rushbrooke E, Brown J, McGovern J i wsp. A pilot study of telepractice delivery for teaching listening and spoken language to children with hearing loss. J Telemed Telecare, 2014; 20(3): 135-40.

13. Elangovan MS. Telehearing and the Internet. Seminars in Hearing Issue, $2005 ; 6(1): 19-25$.

14. Henderson C, Knapp M, Fernández JL, Beecham J, Hirani SP, Cartwright $\mathrm{M}$ i wsp. Cost effectiveness of telehealth for patients with long term conditions (Whole Systems Demonstrator telehealth questionnaire study): Nested economic evaluation in a pragmatic, cluster randomised controlled trial. BMJ, 2013; $1-19$.

15. Hughes ML, Goehring JL, Baudhuin JL, Diaz GR, Sanford T, Harpster R i wsp. Use of telehealth for research and clinical measures in cochlear implant recipients: A validation study. J Speech Lang Hear Res, 2012; 55(4): 1112-27.

16. LeRougea C, Garfieldb MJ, Webb Collins R. Telemedicine: Technology mediated service relationship, encounter, or something else? Int J Med Inform., 2012; 81(9): 622-36.

17. Newton MJ. The promise of telemedicine. Surv Ophthalmol, 2014; 59(5): 559-67.

18. Collins SA, Currie LM, Bakken S, Vawdrey DK, Stone PW. Health literacy screening instruments for eHealth applications: A systematic review. J Biomed Inform, 2012; 45(3): 598-607.
19. Steventon A, Bardsley M, Billings J, Dixon J, Doll H, Hirani S i wsp. Effect of telehealth on use of secondary care and mortality: findings from the Whole System Demonstrator cluster randomised trial. BMJ, 2012; 344: 1-15.

20. Crowell ES, Givens GD, Jones GL, Brechtelsbauer PB, Yao J. Audiology telepractice in a clinical environment: A communication perspective. Ann Otol Rhinol Laryngol, 2011; 120(7): $441-47$.

21. Freeman BA. Technology, legislators, associations, and companies are encouraging tele-audiology. Hearing Journal, 2010; 63(6): 50-51.

22. Givens GD, Elangovan S. Internet application to tele-audiology - "nothin' but net". Am J Audiol, 2003; 12(2): 59-65.

23. Krumm M, Ribera J, Schmiedge J. Using a telehealth medium for objective hearing testing: implications for supporting rural universal newborn hearing screening programs. Seminars in Hearing, 2005; 26(01): 3-12.

24. Lancaster P, Krumm M, Ribera J, Klich R. Remote hearing screenings via telehealth in a rural elementary school. Am J Audiol, 2008; 17(2): 114-22.

25. Laplante-Lévesque A, Pichora-Fuller MK, Gagné JP. Providing an internet-based audiological counselling programme to new hearing aid users: A qualitative study. Int J Audiol, 2006; 45(12): 697-706.

26. Brunnhuber F, Amin D, Nguyen Y, Goyal S, Richardson MP. Development, evaluation and implementation of video-EEG telemetry at home. Seizure, 2014; 23(5): 338-43.

27. van den Berg N, Schumann M, Kraft K, Hoffmann W. Telemedicine and telecare for older patients - A systematic review. Maturitas, 2012; 73: 94-114.

28. Gund A, Sjöqvist BA, Wigert H, Hentz E, Lindecrantz K, Gund $\mathrm{KB}$ i wsp. A randomized controlled study about the use of eHealth in the home health care of premature infants. BMC Medical Informatics and Decision Making, 2013; 13-22.

29. Kotb A, Cameron Ch, Hsieh S, Wells G. Comparative effectiveness of different forms of telemedicine for individuals with heart failure (HF): A systematic review and network meta-analysis. 2015; 10(2): 1-15.

30. Psarros C, Hickson L, Grenness C, Cowan R. Models of audiological service delivery: The Role of Telepractice. Pobrane z: http://www.rrtelehealth.com/presentations/Louise\%20Hickson.pdf

31. Meyers AD. eMedicine otolaryngology: an online textbook for ENT specialists. Ear Nose Throat J, 2000; 79(4): 268-71.

32. Balatsouras DG, Kaberos A, Korres SG, Kandiloros D, Ferekidis E, Economou C. Internet resources available to otolaryngologists. Ann Otol Rhinol Laryngol, 2002; 111(12 Pt 1): 1139-43.

33. Campos PD, Ferrari DV. Teleaudiology: evaluation of teleconsultation efficacy for hearing aid fitting. J Soc Bras Fonoaudiol, 2012; 24(4): 301-8.

34. Lancaster P, Krumm M, Ribera J, Klich R. Remote hearing screenings via telehealth in a rural elementary school. Am J Audiol, 2008; 17(2): 114-22.

35. Convery E, Keidser G, Dillon H, Hartley L. A self-fitting hearing aid: Need and concept. Trends Amplif, 2011; 15(4): $157-66$.

36. Jacobs PG, Saunders GH. New opportunities and challenges for teleaudiology within Department of Veterans Affairs. J Rehabil Res Dev, 2014; 51(5): 7-12. 
37. Nemes J. Tele-audiology, a once-futuristic concept, Is growing into a worldwide reality. Hearing Journal, 2010; 63(2): 19-20, $22-24$.

38. Swanepoel de W, Clark JL, Koekemoer D, Hall JW, Krumm M, Ferrari DV i wsp. Telehealth in audiology: the need and potential to reach underserved communities. Int J Audiol, 2010; 49(3): 195-202.

39. Piotrowska A, Lorens A, Obrycka A, Skarżyński H. Implanty - wczoraj i dziś. Nowa Audiofonologia, 2014; 3(5): 23-27.

40. Kuzovkov V, Yanov Y, Levin S, Bovo R, Rosignoli M, Eskilsson G, Willbas S. Remote programming of MED-EL cochlear implants: users' and professionals' evaluation of the remote programming experience. Acta Otolaryngol., 2014; 134(7): 709-16.

41. McElveen JT, Blackburn EL, Green JD Jr, McLear PW, Thimsen DJ, Wilson BS. Remote programming of cochlear implants: a telecommunications model. Otol Neurotol, 2010; 31(7): 1035-40.

42. Wąsowski A, Skarżyński PH, Lorens A, Obrycka A, Walkowiak A, Bruski L. Remote fitting of cochlear implant system. Cochlear Implants Int, 2010; 11(Suppl.1): 489-92.

43. Wąsowski A, Skarżyński H, Bruski $€$, Lorens A, Obrycka A, Walkowiak A i wsp. Metoda zdalnego dopasowania implantu (telefitting) w Ogólnopolskiej Sieci Teleaudiologii. Nowa Audiofonologia, 2012; 1(3): 39-43.

44. Wesarg T, Wąsowski A, Skarżyński H, Ramos A, Falcon Gonzalez JC, Kyriafinis G i wsp. Remote fitting in Nucleus cochlear implant recipients. Acta Otolaryngol, 2010; 130(12): 1379-88.
45. Kamiński A. Metoda, technika, procedura badawcza w pedagogice empirycznej. W: Wroczyński R, Pilch T. Metodologia pedagogiki społecznej. Wrocław-Warszawa-Kraków-Gdańsk; 1974, 65.

46. Bergmo TS. Using QALYs in telehealth evaluations: A systematic review of methodology and transparency. BMC Health Services Research, 2014, 14: 1-11.

47. Black AD, Car J, Pagliari C, Anandan Ch, Cresswell K, Bokun $\mathrm{T} i$ wsp. The impact of eHealth on the quality and safety of health care: A systematic overview. PLoS Medicine, 2011; 8(1): $1-16$.

48. Linn AJ, Vervloet M, van Dijk L, Smit EG, Van Weert JCM. Effects of eHealth interventions on medication adherence: A systematic review of the literature. J Med Internet Res, 2011; 13(4): $103-23$.

49. Cohn ER, Cason J. Telepractice: A wide-angle view for persons with hearing loss. W: Stredler-Brown A. The Volta Review, 2012; 112(3): 207-26.

50. Yao J, Wan Y, Givens GD. Using web services to realize remote hearing assessment. J Clin Monit Comput, 2010; 24(1): 41-50.

51. Botros A, Banna R, Maruthurkkara S. The next generation of Nucleus fitting: A multiplatform approach towards universal cochlear implant management. Int J Audiol, 2013; 52(7): 485-94.

52. Edirippulige S, Smith AC, Beattie H, Davies E, Wootton R. Pre registration nurses: An investigation of knowledge, experience and comprehension of e health. Aust J Adv Nurs, 2007/2008; 25(2): 78-83. 